\title{
CARE OF OLD PEOPLE IN RESIDENTIAL HOMES
}

BY

\author{
A. E. BENNETT*, м.в., M. DEANE†, в.A., м.P.H., A. ELLIOTT $\ddagger$, M.D., D.P.H., \\ AND \\ W. W. HOLLAND§, M.D., B.Sc.
}

Townsend (1963), in his book "The Last Refugea survey of residential institutions and homes for the aged in England and Wales", painted a disturbing picture of the care received by old people in this country. The purpose of this investigation was to see whether it was possible to make an objective assessment of the adequacies, or the inadequacies, of the residential care given to old people.

This study was performed in the County of Kent. Residential accommodation is provided by the Council under Part III of the National Assistance Act, 1948, and is restricted to provision for persons who by reason of age, infirmity, or any other circumstances are in need of care and attention which is not otherwise available to them. The residential services provided can be divided into five types:

(1) Elderly persons who, while requiring much assistance in such matters as dressing and bathing, are capable of some measure of selfhelp, with nursing in the Home restricted to short periods of illness.

(2) Persons who because of the degenerative changes of age-sometimes occurring prematurely-need a great deal of assistance and substantial measures of care under the supervision of a nurse.

(3) The elderly mentally infirm.

(4) Persons-predominantly men-who, whilst not mentally disordered, need specialized care because they cannot manage on their own in society.

(5) Young persons suffering from degenerative conditions and severe physical handicaps such as multiple sclerosis and severe arthritis.

It has been found necessary by the Council to provide homes appropriate to the special requirements

* Senior Lecturer, Department of Clinical Epidemiology and Social Medicine, St. Thomas' Hospital Medical School, London, S.E.1.

t U.S.P.H.S. Research Fellow, Department of Public Health, Berkeley 4, California, U.S.A.

$\ddagger$ County Medical Officer of Health, Health Department, Kent County Council, Maidstone, Kent.

$\S$ Professor of Clinical Epidemiology and Social Medicine, St. Thomas' Hospital Medical School, London, S.E.1. of persons in these five groups according to the following principles:

(1) Elderly persons with ordinary needs who are better provided for separately from those with special needs. Such an arrangement permits pleasant and harmonious arrangements in the day-to-day life in the homes and is more economic in staffing than if the various types were cared for together.

(2a) Homes for persons having considerable physical infirmity which have more staff regularly on duty because many residents need two attendants for lifting.

(2b) Homes for the elderly mentally infirm which have to have an increased staff ratio because of the high level of incontinence.

(3) Special provisions in co-operation with different organizations such as the Cheshire Foundation Homes for the care of younger persons.

This investigation was limited to homes governed by principles 1 and 2 , e.g. simple residential homes (Type 1 Homes) and homes for the care of persons with advanced physical and mental infirmity (Type 2 Homes). The period of the investigation was November 1,1963 , to December 31, 1965. In 1963 at the beginning of the study there were 24 Type 1 Homes with 848 available places and ten Type 2 Homes with 530 available places. During the period of the study these numbers fluctuated slightly because of various building works and more importantly because of the creation of the Greater London Boroughs in 1965 which took over the administration of part of the Kent County Area. This resulted in transfer of control of eight homes and these lapsed from the study on March 31, 1965.

In addition to studying the experience of persons admitted to residential homes, data were collected on persons remaining in their own homes and receiving the maximum amount of domiciliary care. This was defined as including, amongst other services, both day and evening or night services from the County 
Domestic Help Service staff. It was considered that the experience of this group of persons, whilst obviously not directly comparable, provided some measure for the assessment of institutional care. In the outcome, however, this group proved to be small and comparisons are strictly limited in value.

\section{METHOD}

On November 1, 1963, a census was taken of all residents in all homes of the two types of County Homes selected for study. A data sheet was completed by the Matron or Superintendent of each home for every resident. The data were extracted from individual case records. A similar data sheet was completed for every person in Kent County receiving domiciliary care as previously defined.

The data collected on every individual included: name, sex, civil status, date of birth, place of birth, place of last residence (or present residence for persons in domiciliary care), date of admission to home or domiciliary service, reason for admission, and details of physical state. Subsequently, for every person admitted to a home or receiving domiciliary service during the period of the study, a similar form was completed.

A second data sheet was thereafter completed, recording the date of death or discharge of an individual or if an individual sustained any bony fracture. In the event of death, the diagnosis on the death certificate was recorded: for discharge, the reason was recorded and if this was to hospital, the medical reason for transfer was recorded. For fractures, details of site and cause were recorded. If a person was readmitted to a home or domiciliary services within one month of discharge, the period of care was considered as uninterrupted. Readmission after the lapse of more than $\mathbf{2 8}$ days was treated as a new admission and a new initial data sheet was completed. Deaths occurring within 28 days of discharge were credited as having occurred in the residential homes. In practice such data were only obtained on persons transferred to hospital.

In addition data on each residential home were collected. These gave the size and type of home, number of bathrooms, number of staff, and whether the accommodation was specifically built as a residential home for the old people or what the previous use of the premises had been, i.e. private residence, institution, etc.

\section{Results}

Data are available on a total of 3,593 persons who received care during the 26-month period of the study. Table I shows an analysis by sex and type of care. As can be seen, the proportion of persons re- ceiving both day and night domiciliary care is small ( 5.4 per cent.) in comparison with those in residential care. Although 848 places were available in Type 1 Homes as compared with 530 places in Type 2 Homes, the percentage contribution from each type of home is similar, reflecting an increased turnover of patients in Type 2 Homes. This is not surprising as an increased rate of discharge to hospital and an increased number of deaths is only to be expected due to the infirmities of persons admitted to Type 2 Homes.

TABLE I

NUMBERS OF OLD PEOPLE RECEIVING CARE DURING THE 26 MONTHS OF THE STUDY, BY SEX AND TYPE OF CARE

\begin{tabular}{l|r|r|r|r|r|r}
\hline \multirow{2}{*}{$\begin{array}{l}\text { Place of } \\
\text { Residence }\end{array}$} & \multicolumn{2}{|c|}{ Males } & \multicolumn{2}{c|}{ Females } & \multicolumn{2}{c}{ All } \\
\cline { 2 - 7 } & No. & $\begin{array}{r}\text { Per } \\
\text { cent. }\end{array}$ & No. & $\begin{array}{r}\text { Per } \\
\text { cent. }\end{array}$ & No. & $\begin{array}{r}\text { Per } \\
\text { cent. }\end{array}$ \\
\hline Type 1 Homes & 587 & $58 \cdot 1$ & 1,169 & $45 \cdot 3$ & 1,756 & $48 \cdot 9$ \\
Type 2 Homes & 394 & $39 \cdot 0$ & 1,241 & $48 \cdot 1$ & 1,635 & $45 \cdot 5$ \\
Domiciliary care & 30 & $2 \cdot 9$ & 172 & $6 \cdot 6$ & 202 & $5 \cdot 4$ \\
\hline Total & 1,011 & 100 & 2,582 & 100 & 3,593 & 100 \\
\hline
\end{tabular}

Table II shows the age distribution of all persons admitted to care. Civil status and age is shown in Table III. The mean age at admission of males is less than females-and for single males is somewhat below married and widowed males although this does not hold for females. The ratio of married males to married females admitted is $2 \cdot 8: 1$, but the explanation for this is most likely the obvious one of greater age of male partner of a marriage together with longer survival of females. Of greater interest is the fact that a higher proportion of married males than females receive domiciliary care (33.3 per cent. males; 11 per cent. females) reflecting the importance of care and support received from the spouse. In addition, of females admitted to Type 2 Homes-i.e. homes for advanced physical or mental infirmitymore than twice as many are married than of those admitted to Type 1 Homes, suggesting that a married woman can be cared for by her husband until she has

TABLE II

PERCENTAGE DISTRIBUTION BY SEX AND AGE AT ADMISSION TO RESIDENTIAL HOME OR DOMICILIARY CARE

\begin{tabular}{c|c|c}
\hline $\begin{array}{c}\text { Age Group } \\
\text { (yrs) }\end{array}$ & Males & Females \\
\hline $65-69$ & $9 \cdot 1$ & $6 \cdot 6$ \\
$70-74$ & $12 \cdot 4$ & $11 \cdot 9$ \\
$75-79$ & $23 \cdot 7$ & $20 \cdot 5$ \\
$80-84$ & $28 \cdot 5$ & $26 \cdot 4$ \\
$85-89$ & $18 \cdot 3$ & $23 \cdot 6$ \\
$90-94$ & $6 \cdot 7$ & $9 \cdot 0$ \\
$95+$ & $1 \cdot 3$ & $2 \cdot 0$ \\
\hline Total & 100 per cent. & 100 per cent. \\
& $(1,011$ individuals) & $(2,582$ individuals $)$ \\
\hline
\end{tabular}


TABLE III

PERCENTAGE DISTRIBUTION OF CIVIL STATUS WITH MEAN AGE FOR MALES AND FEMALES

\begin{tabular}{l|c|c|c}
\hline \multicolumn{2}{c|}{ Civil Status } & Male & Female \\
\hline Single & $\begin{array}{c}\text { Per cent. } \\
\text { Mean Age } \\
\text { (yrs) }\end{array}$ & $\begin{array}{c}18 \cdot 1 \\
75.9\end{array}$ & $\begin{array}{l}21 \cdot 2 \\
83.0\end{array}$ \\
\hline Married & $\begin{array}{c}\text { Per cent. } \\
\text { Mean Age } \\
\text { (yrs) }\end{array}$ & $\begin{array}{c}14 \cdot 6 \\
79.8\end{array}$ & 84.6 \\
\hline Widowed & $\begin{array}{c}\text { Per cent. } \\
\text { Mean Age } \\
\text { (yrs) }\end{array}$ & $\begin{array}{c}67.3 \\
80.8\end{array}$ & $73 \cdot 5$ \\
\hline Total & $\begin{array}{c}\text { Per cent. } \\
\text { Mean Age } \\
\text { (yrs) }\end{array}$ & 79.8 & 82.3 \\
\hline
\end{tabular}

reached a more advanced stage of infirmity while the single woman has to be admitted earlier.

Table IV shows reasons for admission to homes in 3-monthly periods. "Living alone" refers to all persons living independently and being unable to continue by reason of age or physical infirmity, sometimes accentuated by unsuitable accommodation. "No accommodation" again refers to persons living independently but for whom the primary reason for admission was loss of accommodation. This was commonly for financial reasons, although eviction, redevelopment of property, etc., was sometimes stated. "Living with relative or friends" refers to persons not living independently and the reason precipitating admission was usually some change in the circumstances of the relative or friend. Births, deaths, and overcrowding were the commonest reasons but included in this group were those admitted in order to allow the persons on whom they were dependent to have a holiday. "Transfer" records those admitted from other institutions.

TABLE IV

PERCENTAGE DISTRIBUTION, MALES AND FEMALES, OF REASON FOR ADMISSION, BY 3-MONTHLY PERIODS

\begin{tabular}{l|r|r|r|r}
\hline \multicolumn{1}{c|}{$\begin{array}{c}\text { Reason for } \\
\text { Admission }\end{array}$} & $\begin{array}{c}\text { Jan.- } \\
\text { March }\end{array}$ & $\begin{array}{c}\text { April- } \\
\text { June }\end{array}$ & $\begin{array}{c}\text { July- } \\
\text { Sept. }\end{array}$ & $\begin{array}{c}\text { Oct.- } \\
\text { Dec. }\end{array}$ \\
\hline Living alone & $44 \cdot 1$ & $45 \cdot 5$ & $31 \cdot 1$ & $51 \cdot 3$ \\
No accommodation & $7 \cdot 9$ & $7 \cdot 0$ & $6 \cdot 3$ & $4 \cdot 5$ \\
$\begin{array}{l}\text { Living with } \\
\text { relative or friend }\end{array}$ & 26.6 & 28.9 & $46 \cdot 1$ & $21 \cdot 1$ \\
Transfer & $21 \cdot 4$ & $18 \cdot 6$ & $16 \cdot 5$ & $23 \cdot 1$ \\
\hline Total & 100 & 100 & 100 & 100 \\
\hline
\end{tabular}

Examination of the figures shows that living alone and failure of independent management are the most common reasons for admission, being highest in the winter months when problems are accentuated. Admission of persons from living with friends or relatives (which includes spouse) is the second highest.
Nearly one half of these admissions result from increase in the third or fourth generation of offspring with resulting inability to continue to care for the aged member of the household, together with overcrowding. Holiday admissions and admission due to death of spouse, relative, or friend each contribute one tenth. Refusal to continue to maintain the aged relative is relatively rare. The effect of holiday admission can be seen in the summer peak for admissions in this group. Transfer from another institution contributes 20 per cent. of admissions, the majority of these being from hospital. The October to March peak reflects the increased number of exchanges of patients resulting from increased need for hospital admissions in the winter months. Admissions for reasons of no accommodation are a small minority least common in the last quarter of the year.

Table $\mathrm{V}$ shows data on the last place of residence of persons admitted to homes. This is expressed as a standardized ratio between areas of Kent County falling within the conurbation of London; towns with a population of $50,000-100,000$, of less than 50,000 , and rural areas. A sharp gradient exists between the conurbation and rural areas for both males and females with proportionately less admissions being derived from the more densely populated areas.

TABLE V

STANDARDIZED RATIO OF ADMISSIONS BY SEX FOR LAST PLACE OF RESIDENCE AS CHARACTERIZED BY THE SIZE OF AREA

\begin{tabular}{l|c|c}
\hline \multicolumn{1}{c|}{ Last Place of Residence } & Male & Female \\
\hline Conurbation & $81 \cdot 6$ & $78 \cdot 8$ \\
$50-100,000$ & $100 \cdot 9$ & $107 \cdot 3$ \\
$<50,000$ & $108 \cdot 8$ & 112.4 \\
Rural & $11 \cdot 4$ & $105 \cdot 4$ \\
\hline Overall & $100 \cdot 0$ & $1100 \cdot 0$ \\
\hline
\end{tabular}

Table VI shows the percentages of persons with various recorded conditions on admission. These data were extracted from medical notes where available and are therefore not uniform. Cardiovascular conditions include any heart disease, angina, hypertension, arteriosclerosis; locomotor disorders include orthopaedic deformity, fractures, amputation, rheumatoid arthritis, arthritis, rheumatism and frailty;

\section{TABLE VI}

PERCENTAGE DISTRIBUTION OF RECORDED CONDITIONS ON ADMISSION, BY SEX

\begin{tabular}{l|c|c|c}
\hline Pathological Conditions & $\begin{array}{c}\text { Type 1 } \\
\text { Homes }\end{array}$ & $\begin{array}{c}\text { Type 2 } \\
\text { Homes }\end{array}$ & $\begin{array}{c}\text { Domiciliary } \\
\text { Care }\end{array}$ \\
\hline Cardiovascular & $9 \cdot 2$ & $\begin{array}{r}8 \cdot 4 \\
\text { Locomotor }\end{array}$ & $\begin{aligned} 15 \cdot 8 \\
\text { Neurological }\end{aligned}$ \\
Partial sightedness & $15 \cdot 5$ & $23 \cdot 4$ & $44 \cdot 6$ \\
& $10 \cdot 0$ & $9 \cdot 3$ & $36 \cdot 1$ \\
\hline
\end{tabular}


neurological conditions include cerebrovascular disease, epilepsy, and senility. Table VI shows that more persons in Type 2 Homes suffer from neurological and locomotor disorders, as would be expected. However, persons remaining in domiciliary care are apparently more diseased than either group, with the exception of partial sightedness.

The subsequent analysis deals with the experience of persons admitted to residential homes in Kent. Where relevant the concept of "person-years at risk" has been employed. The number of person-years at risk of dying, or suffering a fracture, or of being admitted to hospital was calculated separately for each sex and for each 5-year age group for each month of the total period. All subjects were counted as being at risk for a half-month in the month in which they first came under observation and those who died were counted as being at risk for a minimum of a half-month in the month of their death, and similarly for those who sustained a fracture or were admitted to hospital. Those who died, suffered a fracture, or were admitted to hospital in the month in which they came under observation were counted as being at risk for a quarter of a month.

In the period under study 552 deaths occurred. Applying age-specific and sex-specific mortality rates for England and Wales to the population at risk, after calculation of the person-years at risk, gives the expected number of deaths as 408 . Thus the ratio of observed to expected is $1 \cdot 35$, showing an increase of approximately one-third. In view of the factors influencing selection of the population under study this increase is not remarkable.

There were ninety fractures in the study population, none of which occurred in persons receiving domiciliary care. Twelve fractures occurred in males and 78 in females. Of the ninety fractures, 71 involved the femur. Table VII shows the rates for fracture of the femur by sex for the population under study with data derived from mental hospitals (Leitch, Knowelden, and Seddon, 1964) and Oxford and Dundee (Knowelden, Buhr, and Dunbar, 1964). The results show that, with the exception of males aged between 65 and 74 in whom no fractures occurred, the rates for Kent homes are in all cases in excess of general population rates. In addition for females they are in excess of rates for mental hospitals.

The annual rate of hospital admission per 1,000 for males was $100 \cdot 99$ and for females $72 \cdot 05$. This compares favourably with data in the Hospital InPatient Enquiry for 1962, where rates for hospitalization are $151 \cdot 83$ for males and $112 \cdot 11$ for females.

A further analysis of mortality is shown in Table VIII. This shows the percentages of deaths occurring in consecutive 6-monthly periods. In Type I Homes there is an excess of male deaths in the first 6 months but not of females. In Type 2 Homes there is an excess of both male and female deaths in the first 6 months after admission.

\section{TABLE VIII}

EXPERIENCE OF OLD PEOPLE ADMITTED TO AND DYING IN RESIDENTIAL HOMES, SHOWING PERCENTAGE OF DEATHS OCCURRING IN 6-MONTHLY PERIODS AFTER ADMISSION

\begin{tabular}{c|c|c|c|c}
\hline & \multicolumn{2}{|c|}{ Type 1 Homes } & \multicolumn{2}{c}{ Type 2 Homes } \\
\cline { 2 - 5 } & Males & Females & Males & Females \\
\hline 6-Month Period & $24 \cdot 3$ & $17 \cdot 0$ & $39 \cdot 2$ & $31 \cdot 4$ \\
\hline $0-5$ & $14 \cdot 4$ & $18 \cdot 9$ & $23 \cdot 5$ & $16 \cdot 4$ \\
$6-11$ & 11.7 & $9 \cdot 4$ & $17 \cdot 6$ & $13 \cdot 2$ \\
$18+$ & $49 \cdot 6$ & $54 \cdot 7$ & $19 \cdot 7$ & $39 \cdot 0$ \\
\hline Total & 100 & 100 & 100 & 100 \\
\hline
\end{tabular}

Analyses were performed to examine whether the characteristics of the individual homes influenced mortality, fracture, and hospital admission rates. Four characteristics were calculated for each home, viz. staff:patient ratio; bedroom: patient ratio; bathroom:patient ratio; and W.C.: patient ratio. The range of these ratios is shown in Table IX (opposite) and is of such a magnitude as to be considered meaningful.

Rank order correlation coefficients were calculated for mortality, fracture, and hospital admission rates and these ratios. The results are shown in Table $\mathrm{X}$ (opposite).

It may be seen that there is a highly significant negative correlation between staff: patient ratios and mortality rate, i.e. the less staff the higher the mortality rate in individual homes. In addition, there is a

TABLE VII

AVERAGE ANNUAL AGE-SPECIFIC INCIDENCE RATES PER 1,000 FOR FRACTURE OF THE FEMORAL NECK AND TROCHANTER IN KENT HOMES, OXFORD AND DUNDEE 1954-58, AND SEVEN LONDON MENTAL HOSPITALS 1954-58

\begin{tabular}{|c|c|c|c|c|c|c|}
\hline \multirow{2}{*}{$\begin{array}{c}\text { Age } \\
\text { Group } \\
\text { (yrs) }\end{array}$} & \multicolumn{3}{|c|}{ Males } & \multicolumn{3}{|c|}{ Females } \\
\hline & $\begin{array}{l}\text { Kent } \\
\text { Homes }\end{array}$ & $\begin{array}{l}\text { Oxford and } \\
\text { Dundee }\end{array}$ & $\begin{array}{c}\text { Mental } \\
\text { Hospitals }\end{array}$ & $\begin{array}{c}\text { Kent } \\
\text { Homes }\end{array}$ & $\begin{array}{l}\text { Oxford and } \\
\text { Dundee }\end{array}$ & $\begin{array}{c}\text { Mental } \\
\text { Hospitals }\end{array}$ \\
\hline $\begin{array}{c}65-74 \\
75-84 \\
85+\end{array}$ & $\begin{array}{r}\overline{9} \cdot 34 \\
17 \cdot 85\end{array}$ & $\begin{array}{l}0 \cdot 78 \\
3 \cdot 02 \\
6 \cdot 34\end{array}$ & $\begin{array}{r}4 \cdot 42 \\
13 \cdot 89 \\
21 \cdot 16\end{array}$ & $\begin{array}{l}26 \cdot 42 \\
24 \cdot 59 \\
32 \cdot 76\end{array}$ & $\begin{array}{r}1 \cdot 59 \\
6 \cdot 33 \\
19 \cdot 26\end{array}$ & $\begin{array}{r}6 \cdot 73 \\
19 \cdot 75 \\
28 \cdot 47\end{array}$ \\
\hline
\end{tabular}


TABLE IX

HIGHEST AND LOWEST VALUES FOR RATIOS OF SELECTED CHARACTERISTICS

\begin{tabular}{l|c|c}
\multicolumn{1}{c|}{ Ratio } & Highest & Lowest \\
\hline Staff: patient & 0.67 & 0.33 \\
Bedroom: patient & 0.86 & 0.16 \\
Bathroom: patient & 0.55 & 0.05 \\
W.C.: patient & 0.32 & 0.13 \\
\hline
\end{tabular}

TABLE X

RANK CORRELATION COEFFICIENTS FOR HOME CHARACTERISTICS AND MORTALITY, FRACTURE, AND HOSPITAL ADMISSION RATES

\begin{tabular}{l|c|c|c}
\hline \multicolumn{1}{c|}{ Ratio } & Mortality & Fracture & $\begin{array}{c}\text { Hospital } \\
\text { Admission }\end{array}$ \\
\hline Staff: patient & $-0.4584^{*}$ & -0.1250 & -0.2396 \\
Bedroom: patient & $\mathbf{- 0 . 0 5 7 9}$ & -0.0710 & -0.0018 \\
Bathroom: patient & +0.0167 & $-0.3410+$ & -0.1456 \\
W.C.: patient & +0.0069 & -0.1890 & +0.0287 \\
\hline
\end{tabular}

$.0 .01>P>0.005$

$+0.05>P>0.025$

significant correlation between the bathroom: patient ratio and fracture rates, i.e. the fewer bathrooms the higher the fracture rate. Whereas the first finding is not unexpected and the probability of its occurring by chance is small, some reservations must be held about the significance of the second finding. 48 correlation coefficients were calculated, twelve for all homes together and an additional 36 for the three classes of buildings separately. It is not surprising, therefore, that, in addition to the highly significant $(\mathrm{P}<0.01)$ finding for mortality and staff: patient ratio, two other correlations showed statistical significance at the 5 per cent. level of probability.

The finding on mortality was further analysed. Homes were divided into three classes according to their origin. Of the 34 homes, nine were purposebuilt, nineteen were converted private residence, and six had been hospital or convalescent homes. Thus they differed in characteristics considerably. Rank order correlation coefficients were calculated for mortality and staff:patient ratio within each class of building. For purpose-built accommodation $\left(r_{s}=\right.$ $-0 \cdot 154)$ and for former hospital accommodation $\left(r_{s}=-0.233\right)$ the results are not significant. For converted accommodation $\left(r_{s}=-0.556 ; 0.02>\mathrm{P}\right.$ $>0.01)$ there is a significant correlation. Although not achieving significance, the sign of the correlation coefficient for purpose-built and former hospital accommodation is consistently negative.

Further analysis was undertaken to determine whether the overall size of the home was important. It was found that mortality was highly correlated with size of the home $\left(r_{s}=+0.548 ; 0.01>\mathrm{P}>\right.$ 0.001 ), i.e. the larger the home the higher the mor- tality. There was no significant correlation between the size of the home and the staff:patient ratio $\left(r_{s}=\right.$ $+0.007)$. However, when the homes were divided into Type 1 Homes and Type 2 Homes and rank correlation coefficients were calculated for mortality and size of home, both were found to be not significant $\left(r_{s}(\right.$ Type 1$)=+0.235: r_{s}($ Type 2$\left.)=+0.054\right)$.

The finding of a significant correlation between the size of homes and mortality rates is, therefore, spurious and due entirely to the fact that homes for advanced physical infirmity are larger and have, as would be expected, a higher mortality rate. As staff: patient ratio does not in any analysis significantly correlate with size, it would thus appear that the correlation of staff:patient ratio with mortality is independent and meaningful.

\section{Discussion}

Several findings of importance emerge from this study. The proportionately higher admission rates from the less densely populated areas are unexpected. This may be due to migration of the younger generations to urban and larger areas, leaving parents living in isolation. The onset of the physical infirmities of old age then means that, with no family support, independent existence becomes more difficult. In addition, it is possible that living in less densely populated areas results in general increase in social isolation, so that all forms of support are diminished. Alternatively, the effectiveness of the functioning of the health and welfare services in less densely populated areas must be questioned.

The increased proportion of deaths amongst males in the first 6 months after admission to Type 1 Homes may be due to a period of unsettlement or at least in part to the effects of bereavement. However, both males and females are affected in Type 2 Homes and it would, therefore, be advisable to regard all new admissions to care as a special group with a high mortality risk.

The correlation of mortality with staffing is not altogether unexpected. At inadequate levels of staffing the needs of old people are probably not fully met and the deficiencies might find expression in an increased mortality. The staffing establishments of the homes under study could not by national standards be considered of a low or unsatisfactory order, and to show an effect in situations which by such standards appear satisfactory is perturbing. That the type of building and the provision of other facilities could not be shown to be related to mortality is probably an indication of a general high standard of accommodation.

However, in spite of this, the fracture rate for femurs in female residents is shown to be higher than 
in mental hospital patients. Fracture rates for both sexes are higher than in the normal population. Some confirmation for this finding exists in the absence of recorded fractures amongst persons receiving domiciliary care. The population of Type 1 and Type 2 Homes is obviously not comparable with the normal population and not necessarily comparable with mental hospital population. However, comparisons with mental hospital patients could be expected to favour persons in homes. In spite of this the experience of females is somewhat worse. Before conclusions about the reasons for this can be reached, further study is necessary to determine how the fractures occur. For example, it may be that residents in old people's homes are encouraged to be more active and are therefore at greater risk, or that a much larger proportion of mental hospital inpatients within the age range under study is bedfast and therefore more protected from the risk of injury.

The County homes are shown to have a favourably low rate of hospital admission. This may be because residents who become sick receive nursing care without the need for hospital admission, while excess of hospital admissions in the normal population of the same ages may reflect the numbers of aged people who are admitted to hospitals for social rather than for medical reasons.

\section{CONCLUSION AND Summary}

The purpose of this study was to determine whether it was possible to make objective assessments of the care given to residents in old people's homes. The results presented, as well as providing sociological $\frac{2}{\mathbb{D}}$ data for further study, show that the rate for mor- ? tality, fractures, and hospital admissions provide possible measures.

Residents in old people's homes showed an excess of fractures during the period of the study. Mortality rates were increased by one-third; rates for hospital admission were reduced by approximately one-third. Mortality is shown to be significantly correlated के with the staff:patient ratio.

We acknowledge with gratitude the help of the $\stackrel{\omega}{\omega}$ Matrons and Supervisors who were responsible for so $\vec{\nabla}$ much of the data collection; Miss Mary Manford, $\stackrel{\circ}{?}$ Mrs Janet Blake, and Miss Mary Morgan for assistance with data processing; Mr S. G. Nicholas for the preparation of punch cards; and Imperial College London for $\overrightarrow{\vec{D}}$ computer facilities. M. Deane was in receipt of U.S. $\mathscr{\omega}$ Public Health Service Fellowship No. F3AP928.

\section{REFERENCES}

Knowelden, J., Buhr, A. J., and Dunbar, O. (1964). Brit.J. 음 prev. soc. Med., 18, 130 (Incidence of fractures in per- $\mathbb{\Phi}$ sons over 35 years of age).

Leitch, I. H., Knowelden, J., and Seddon, H. J. (196 Ibid., 18, 142 (Incidence of fractures, particularly of the neck of the femur, in patients in mental hospitals).

Townsend, P. (1963). "The Last Refuge-a Survey of Residential Institutions and Homes for the Aged in England and Wales." Routledge and Kegan Paul, London. 